\section{Wildfires in Portugal}

\section{Domingos Xavier Viegas}

ADAI, Department of Mechanical Engineering, Faculty of Sciences and Technology, University of Coimbra, Portugal

In 2017 Portugal was devastated by forest fires that destroyed more than 500 thousand hectares and claimed at least 112 lives. The country was plagued with a severe drought that raised the risk of fire and was caught by two prominent episodes of extreme conditions: one in mid-June and another in mid-October that caused the greatest damages.

On the $17^{\text {th }}$ June in the mid of a heat wave with temperatures above $40^{\circ} \mathrm{C}$ and relative humidity below $20 \%$ in the Central Region of Portugal a series of fire events were started partially by a thunderstorm but also due to other causes. One of these fires in the municipality of Pedrógão Grande was influenced by the thunderstorm and went out of control spreading very rapidly during few hours causing the death of 66 persons in a relatively small part of the territory. This fire was extinguished only on the $23^{\text {rd }}$ June after burning more than 47 thousand hectares. In about one hour the fire spread about 4000 hectares from approximately 2940 to 6740 hectares.

A detailed study of this fire carried out under the supervision of the Author put in evidence that most fatalities occurred while citizens were fleeing from their homes usually by car and being caught in the middle of smoke and flames when they reached even main roads. In a particular stretch of the road N236-1, 31 persons were killed by the fire inside or near their cars. Most of them were running away from their nearby houses. Although more than 250 houses were burned only four persons perished inside their homes, all of them with mobility problems. The majority of the houses was impacted by embers that ignited weak points of the structure, usually the roof. In Portugal most houses have ceramic tiled roofs with a wooden structure that makes them relatively vulnerable to fire.

Given the persistence of very fire prone conditions during the months of July, August and September there were severe fires threatening villages and even some cities forcing the authorities to evacuate several places to avoid loss of lives. In this period, Portugal lost more than 100 thousand hectares that is what is lost in average in a normal year.

On the $15^{\text {th }}$ October, under the influence of Ophelia tempest that induced a very strong, dry and hot southerly wind over the coastal region, several fires became rapidly out of control. Long distance spotting multiplied the number of ignitions that were far above the capability of the fire fighting forces. In less than 24 hours these fires destroyed more than 200 thousand hectares and claimed 46 lives.

This second wave of fires reached a much wider area in the Centre and North of Portugal virtually from the Atlantic to the mountains and destroyed several industrial areas, causing great economic losses and the immediate loss of hundreds of jobs.

Several factors contributed to the occurrence of these dramatic fire events. Besides socio economic changes in the land use, human occupation and management of the rural areas, wrongly oriented policies for the management of the problem, together with climatic changes. In the past decades, the frequency of extreme fire danger conditions have increased as well as the extension of the period of fire prone days. In 2017, we had two fires that burned more than 50 thousand hectares each, which was unheard in the past. Only after 1990, fires with more than 10 thousand hectares were recorded in Portugal. In the past years, this limit has been increasing steadily to 20,30 , to 40 and now to 50 thousand hectares. We cannot fail to mention the fact that most fires (above 90\%) in Portugal are caused by
Correspondence: Domingos Xavier Viegas, ADAI, Department of Mechanical Engineering, Faculty of Sciences and Technology, University of Coimbra, Portugal. Tel.: +351.239790732

E-mail: xavier.viegas@dem.uc.pt

Key words: Wildfires; Portugal.

Received for publication: 12 December 2017. Accepted for publication: 12 January 2018.

This work is licensed under a Creative Commons Attribution 4.0 License (by-nc 4.0).

(C) Copyright D.X. Viegas, 2018

Licensee PAGEPress, Italy

Fire Research 2018; 2:52

doi:10.4081/fire. 2018.52

human activity. The majority of them is caused by accident or by carelessness but a non-negligible proportion (of the order of $15 \%$ ) is caused by arson. Unfortunately this last cause has been responsible in past for some very large fires and accidents.

The problem of forest fires raises great challenges to the scientific community and has been addressed by several research Groups in the World. Unfortunately in Europe there is not a consistent research program on this issue and the scientific community is dispersed in several intermittent projects involving only part of the research Groups. In Portugal the situation is similar although the 2017 fire events triggered the intention from the Government to promote this field of research in the coming years.

Several other policy changes are being carried out in Portugal to cope with the problem. These include the creation of a Government Agency to coordinate the fire management issues and the proposal of several actions. Given the complexity of the problem one cannot expect that these measures will solve it in a short period but hopefully they will contribute to minimize the problem. 